\title{
Biomechanical Comparison of Different Subtrochanteric Bone Fracture Angles in Cerclage Wiring: Finite Element Study
}

\section{Serklaj Kablolamada Farklı Subtrokanterik Kemik Kırılma Açılarının Biyomekanik Karşılaştırılması: Sonlu Eleman Çalışması \\ R. Bugra Husemoglu', Hasan Havitcıoglu', 2}

'Dokuz Eylul University, Institute of Health Sciences, Department of Biomechanics, Izmir, Turkey

${ }^{2}$ Dokuz Eylül University Faculty of Medicine Hospital, Department of Orthopedics and Traumatology, Izmir, Turkey

\section{Abstract:}

Cerclage wires are regularly hired as fixation gear to resource reposition, enhance alignment and growth fixation stability. In specific femoral shaft, subtrochanteric and periprosthetic fractures gain from cerclage fixation. Also in supracondylar femoral shaft fractures, extra cord cerclages proved to be extra than only a reposition device and accelerated the general power of the osteosynthesis construct. This study tests for the stabilizing effect of different bone fracture angles in with cerclage. Cerclage fixation of a oblique fractures were tested with fracture angles $\left(45^{\circ}, 55^{\circ}, 65^{\circ}\right)$. Construct stiffness and displacements were investigated under static loads and compared to the different bone fracture angles. With each of the tested bone fractures, stiffness wasn't significantly for a compare angles. Most reduction in fracture gap movement was achieved by $65^{\circ}$ fracture angle, followed by $55^{\circ}$ and $45^{\circ}$ fractures.

All cerclage wire fixation were generally superior with reduced fracture movements whereas in 65 degree fracture showing the greatest stabilizing effect. Cerclage wire application has emerged as a potential therapeutic for subtrochanteric fractures.

Keywords: Oblique Fractures, Cerclage Wire, Bone Fracture Angle, Finite Element Analysis

Özet:

Serklaj telleri, yeniden konumlandırmaya yardımcı olmak, hizalamayı iyileştirmek ve sabitleme stabilitesini artırmak için sabitleme araçları olarak sıklıkla kullanılır. Özellikle femur şaftı, subtrokanterik ve periprostetik kırıklar serklaj fiksasyonundan yararlanır. Ayrıca suprakondiler femur şaft kırıklarında, ek olarak tel serklajların tespit aracından daha fazlası olduğu ve osteosentez yapısının genel mukavvemeti arttırdığı kanıtlanmıştır. Bu çalışma, serklaj ile farklı kemik kırılma açılarının stabilize edici etkisini test etmektedir. Oblik kırıkların serklaj fiksasyonu kırık açıları ile test edildi $\left(45^{\circ}, 55^{\circ}, 65^{\circ}\right)$. Yapı rijitliği ve yer değiştirmeler, statik yükler altında incelendi ve farklı kemik kırılma açılarıyla karşılaştırıldı. Test edilen kemik kırıklarının her birinde sertlik, karşılaştırma açılarında anlamlı bulunmadı. Kırık boşluğu hareketindeki en azalma, $65^{\circ} \mathrm{kırılma} \mathrm{açısı} \mathrm{ile} \mathrm{sağlandı,} \mathrm{bunu} 55^{\circ}$ ve $45^{\circ} \mathrm{kırıklar} \mathrm{izledi.}$

Tüm serklaj teli fiksasyonu, kırık hareketlerini azaltmış ve genel olarak rijit bulunmasının yanında, en büyük stabilize edici etkiyi 65 derecelik kırıkta gösterdi. Serklaj teli uygulaması, subtrokanterik kırıklar için potansiyel bir terapötik olarak ortaya çıkmıştır.

Anahtar Kelimeler: Oblik kırıklar, serklaj kablolama, kemik kırık açısı, sonlu elemanlar analizi

Correspondence Address : R. Buğra Hüsemoğlu,

ORCID ID of the authors: R.B.H. 0000-0003-1979-160X,

Dokuz Eylul University, Institute of Health

H.H.. 0000-0001-8169-3539

Sciences, Department of Biomechanics, Izmir,

Turkey bugrahusem@gmail.com

Please cite this article in press at: Husemoglu R.B., Havitcioglu H., Biomechanical Comparison of Different Subtrochanteric Bone Fracture Angles in Cerclage Wiring: Finite Element Study, Journal of Medical Innovation and Technology, 2021; 3 (2):35-39 doi: 10.51934/jomit.1052710 


\section{Introduction}

Cerclage wiring is a simple technique that has been practiced widely since the advent of surgical treatment of fractures. The indications for cerclage as an exclusive implant were limited because other technologies offer a better outcome, while the increasing numbers of periprosthetic fractures has led to a revival of interest for this simple technique.

Cerclage wires have long been used for the fixation of diaphyseal fractures, either alone or in combination with other fixation methods [1]. Cerclage wires are often hired as fixation equipment to useful resource reposition, enhance alignment and increase fixation stability. In particular femoral shaft, subtrochanteric and periprosthetic fractures advantage from supplementary cerclage fixation [2],[3]. Also in supracondylar femoral shaft fractures, extra cord cerclages proved to be extra than only a reposition device and increased the overall strength of the osteosynthesis construct [4].

Cerclage wires are a non-reactive stainless steel alloy, that's a ways extra malleable than the stainless steel alloy used to make bone plates or pins. There are three primary sorts of cerclage wiring, complete cerclage, hemicerclage wiring and tension band wiring, that's a specialized shape of hemicerclage. Full circlage wiring utilizes a full circumferential wire placed around the bone at a fracture site. This use is generally restricted to the diaphyseal segments of long bones. The fracture is carefully reconstructed and the fragments are wired in place prior to applying the definitive form of fixation. Full cerclage anatomic reconstruction of the fracture at the level of the cerclage wire is mandatory, otherwise the fragments will move and collapse and the wire will loosen[5].

Full cerclage wiring is best appropriate for long oblique diaphyseal fractures where the length of the fracture is greater than twice the diameter of the bone at the fracture site $\left(>45^{\circ}\right)$. If the fracture line is greater than two times the diameter of the bone on the fracture site, the wire will acquire inter-fragmentary compression[6].

Finite element (FE) evaluation is a effective biomechanical device that permits for the manage of numerous parameters, such as loading forces, fracture kind and implants, that might in any other case be tough to evaluate in vivo or thru cadaveric experiments.Therefore, in this study, oblique bone fracture angles evaluate their differences using finite element analysis.

\section{Materials and Methods}

The bone and cerclage wire models was created using the Solidworks software (Dassault Systemes Simulia Corp., Providence, RI, USA). According to the anatomic femur diaphysis based, cylindrical bone specimens were performed. Cylindrical bone samples dimmentions were $030 \mathrm{~mm}$ and lenghts $100 \mathrm{~mm}$. Monofilament cerclage wire model created was dimmentions $032 \mathrm{~mm}$ and thickness $1.5 \mathrm{~mm}$. In this study, three different bone fracture models were compared. All solid models were imported to analysis software (ANSYS 2020 R1, ANSYS Inc., Houston, TX, USA).

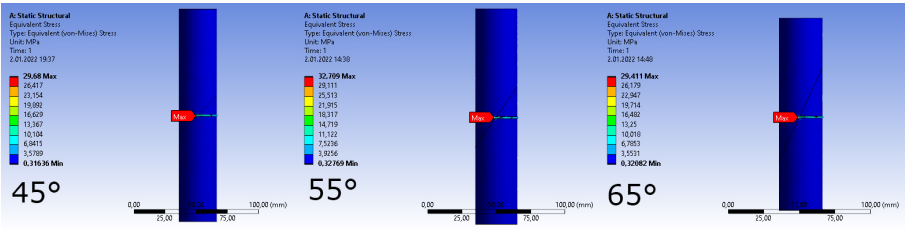

Fig. 1 - Bone specimens and Monofilament Cerclage Wires

Based on the results of the mesh convergence analysis, $2 \mathrm{~mm}$ element edge lengths were used for all components. The bone was represented with a single isotropic elastic modulus of $17,000 \mathrm{MPa}$. A uniform Poisson's ratio of 0.3 was assigned for all bone elements.

A vertical load $800 \mathrm{~N}$, was applied to the proximal. The stress over the cerclage component was evaluated every angle performing a osteotomy. The following material properties were considered for the study as shown in Table 1.

Table 1. Mechanical properties of bone and cerclage wire

\begin{tabular}{|l|l|l|l|}
\hline Element & Material Properties & Cortical Bone & Cerclage Wire \\
\hline 1. & Young's modulus & $17 \mathrm{GPa}$ & $186 \mathrm{GPa}$ \\
\hline 2. & Density & $2 \mathrm{gm} / \mathrm{cm} 3$ & $1.08 \mathrm{gm} / \mathrm{cm} 3$ \\
\hline 3. & Poisson's ratio & 0.38 & 0.3 \\
\hline
\end{tabular}

In the present study, the bone was assumed to be as linear isotropic material [7],[8] . The analysis was carried out for loads $800 \mathrm{~N}$. The distal end of the bone specimen was constrained in accordance with the previous works [9].

Contact between bone and implant, and between bone fragment was considered to be frictional. The coefficient of friction for the bone-to-bone, bone-to-implant and implant-to-implant contacts were 0.46 , and 0.2 , respectively [10]. 


\section{Results}

\section{Comparison of Bone Fracture Angles}

The stress was evaluated proximal at $800 \mathrm{~N}$ with for $45^{\circ}$ the maximum stress $(29,68 \mathrm{MPa}), 5^{\circ}$ the mean stress $(32,70 \mathrm{MPa})$ and for $65^{\circ}(29,41 \mathrm{MPa})$ (Table 2$)$

The maximum stress of the monofilament cerclage wire was at the anterior medial position of the specimen, as shown in Figure 2.

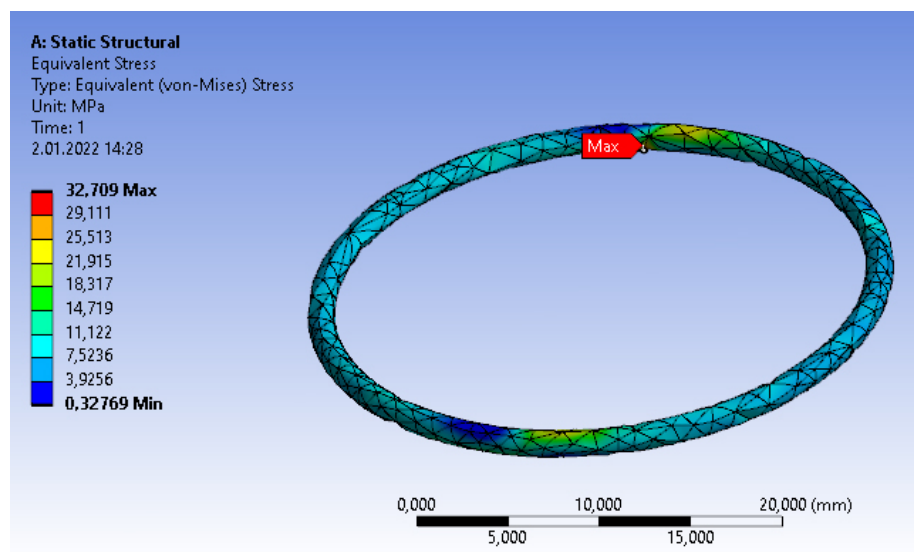

Fig.2 - Maximum Stress of the Monofilament Cerclage Wire

Table 2. Cerclage wire stress values

\begin{tabular}{|c|c|c|c|c|}
\hline Fracture Angle & Uzama & \multicolumn{3}{|c|}{ Stress (MPa) } \\
\hline Specimen & Max & Min & Max & Avarage \\
\hline $45^{\circ}$ & 0,013573 & 0,31636 & 29,68 & 3,0947 \\
\hline $55^{\circ}$ & 0,013043 & 0,32769 & 32,709 & 3,1439 \\
\hline $65^{\circ}$ & 0,011842 & 0,32082 & 29,411 & 3,0909 \\
\hline
\end{tabular}

\section{Discussion}

This study demonstrates stabilizing effect of angles of fractures on cerclage wiring of oblique fractures. While previous studies focused only on stand-alone cerclage configurations and techniques our study provided a comparison of different bone fracture angle types in a relevant fracture model.

Although augmentation of fracture fixation through cerclages has an enduring tradition and has tested to be clinically successful, its biomechanical implications have now no longer but been explored sufficiently. In addition to its use as a brief percutaneous reduction clamp, a cerclage also can be carried out as an extra stabilization device to enhance the stability of the osteosynthesis.
The bone must have stable anatomical reduction over a complete turn at the level of application or the compression produced by the wire will purpose the bone to collapse or fragment further.

Cerclage wiring is most suited to long oblique fractures where the length of the fracture is greater than two times the diameter of the bone at the fracture site. If the fracture line is greater than two times the diameter of the bone at the fracture site, the wire will achieve inter-fragmentary compression. If the length of the fracture line is much less than two times the bone diameter then shearing forces may be produced on the way to disrupt the fracture [6].

In recent literature, fracture fixation with cerclage wiring is known to be associated with implant-related complications due to secondary fracture displacement and implant migration [11]. Biomechanical studies have revealed that lag screw configurations are stiffer compared with cerclage wiring or cable systems [12], Thus, we were concerned whether the circumferential cerclage would become reduced stiffness during static loading, especially in this idealized 3D bone model. Even 65 degrees bone fracture with loads in excess of physiological loads we were not able to detect too much loosening or migration.

Early weight-bearing regimes are related to decrease hazard of complications, for example better functional outcome at early levels of rehabilitation [13]. Modern fracture care prioritizes rapid return to function as well as patient autonomy and convenience, which can be enhanced by post-operative mobilization and weight-bearing to an extent the patient feels snug with [14].

Some limitations of this study need to be mentioned. Biomechanical in vitro studies have the inherent weakness that in vivo situation. However, it should be noted that the aim was to investigate the clinical trends rather than absolute values. Our load protocols included post-operatively acceptable values for moderate as well as excessive weight-bearing up to $800 \mathrm{~N}$. Cerclage wiring is obviously limited to oblique or spiral fractures and has no further stabilizing effect in transverse or comminuted fractures. 


\section{Conclusion}

The indications for cerclage as an exclusive implant were limited, while this simple technique is frequently used to secure femoral fractures, allografts and plates, especially in periprosthetic fractures. In conclusion, we demonstrated the stabilizing effect of different bone fracture angles cerclage materials.

The findings from this study favor a cable cerclage, as it was able to better reinforce osteosynthesis in terms of higher stiffness and reduced interfragmentary movements. Whether our results can be transferred into the clinical routine has to be investigated in further clinical studies. In this results, bone structure represents the actual femur anatomy and therefore, FEM analysis should take into account the properties of individual layers that constitute the femur for accurate analysis. 


\section{References}

1. A. Angelini and - Concetto Battiato, "Past and present of the use of cerclage wires in orthopedics," Eur. J. Orthop. Surg. Traumatol.

2. K. Gordon, M. Winkler, T. Hofstädter, U. Dorn, and P. Augat, "Managing Vancouver B1 fractures by cerclage system compared to locking plate fixation - a biomechanical study," Injury, vol. 47 Suppl 2, pp. S51-S57, Jun. 2016.

3. P. Codesido, A. Mejía, J. Riego, and C. Ojeda-Thies, "Subtrochanteric fractures in elderly people treated with intramedullary fixation: quality of life and complications following open reduction and cerclage wiring versus closed reduction."

4. C. Bliemel et al., "More than a reposition tool: additional wire cerclage leads to increased load to failure in plate osteosynthesis for supracondylar femoral shaft fractures," Arch. Orthop. Trauma Surg., vol. 141, no. 7, pp. 1197-1205, Jul. 2021.

5. R. J. Boudrieau and K. R. Sinibaldi, "Principles of long bone fracture management.," Semin. Vet. Med. Surg. (Small Anim)., vol. 7, no. 1, pp. 44-62, 1992.

6. D. P. Akira Takeuchi, "World Small Animal Veterinary Association World Congress Proceedings, 2003," VIN.com, Jul. 2014.

7. "Probabilistic finite element analysis of the uncemented hip replacement-effect of femur characteristics and implant design geometry I Elsevier Enhanced Reader." [Online]. Available: https://reader.elsevier.com/reader/ sd/pii/S0021929009005582?token $=687 D 07 D 3604 D 056188$ B9CAB6DDD98FFA96CBA761AB7294C7FBD2885A2544FB 6A43D9FD59482B9AC73BF37058C93BEC76\&originRegio $\mathrm{n}=\mathrm{eu}$-west-1\&originCreation $=20211230094228$. [Accessed: 30-Dec-2021].

8. G. E. Cook et al., "Biomechanical optimization of the angle and position for surgical implantation of a straight short stem hip implant," Med. Eng. Phys., vol. 39, pp. 23-30, Jan. 2017.
9. V. M. M. Lopes, M. A. Neto, A. M. Amaro, L. M. Roseiro, and M. F. Paulino, "FE and experimental study on how the cortex material properties of synthetic femurs affect strain levels," Med. Eng. Phys., vol. 46, pp. 96-109, Aug. 2017.

10. J. M. Goffin, P. Pankaj, and A. H. Simpson, "The importance of lag screw position for the stabilization of trochanteric fractures with a sliding hip screw: a subjectspecific finite element study," J. Orthop. Res., vol. 31, no. 4, pp. 596-600, Apr. 2013.

11. M. Nienhaus, I. Zderic, D. Wahl, B. Gueorguiev, and P. M. Rommens, "A locked intraosseous nail for transverse patellar fractures: A biomechanical comparison with tension band wiring through cannulated screws," J. Bone Jt. Surg. - Am. Vol., vol. 100, no. 12, p. E83, Jun. 2018.

12. H. S. Matloub, P. L. Jensen, J. R. Sanger, B. K. Grunert, and N. J. Yousif, "Spiral Fracture Fixation Techniques: A biomechanical study," http://dx.doi.org/10.1016/02667681(93)90162-9, vol. 18, no. 4, pp. 515-519, Aug. 2016.

13. G. Meys et al., "A protocol for permissive weight-bearing during allied health therapy in surgically treated fractures of the pelvis and lower extremities," J. Rehabil. Med., vol. 51, no. 4, pp. 290-297, 2019.

14. N. Dehghan et al., "Early weightbearing and range of motion versus non-weightbearing and immobilization after open reduction and internal fixation of unstable ankle fractures: A randomized controlled trial," J. Orthop. Trauma, vol. 30, no. 7, pp. 345-352, Jul. 2016. 